\title{
BUILDING PLANES AND LEARNING STANDARD COSTING: A STUDENT- CENTERED APPROACH
}

\author{
Luciane Reginato 1 \\ Edgard B. Cornacchione 2
}

\author{
- Received: 07/16/2019 -- Approved: 05/22/2020 -- Second Approved Version: 02/08/2020
}

\begin{abstract}
Driven by a continuing debate about the management accounting career evolution and the influence of instructional strategies on student performance, this study focuses on active learning strategies in managerial accounting courses. Based on Kolb's experiential learning theory, a quasi-experiment was developed to assess the effect of a guided aviation manufacturing hands-on team-based case in teaching standard costing to business administration majors. Evidence was gathered from four cohorts of a cost accounting undergraduate course in a large public research university in Brazil. A total of 219 students participated in the study. The instructor taught all groups under identical conditions on a weekly basis. Data processing included descriptive statistics, a paired test (experimental hypothesis), and wordclouds. In addition, experts (faculty in the field) validated the results. Results are robust (Cohen's $d$ of 1.026) and indicate that the experimental group demonstrate significant pre- to post-test improvement in exam performance, compared to the control group, with a large effect size. Contributions of the study aimed at transferring learning that favors students approach to real life and the development of social skills (student builds, interacts and manages an activity working in teams); a positive experience that may encourage faculty and program administrators to use more active instructional strategies; and preparing the students for the market, developing professionals with demanded working skills.
\end{abstract}

Keywords: Standard Costing. Active Learning. Accounting Education.

\footnotetext{
${ }^{1} \mathrm{PhD}$ in Accountancy from University of São Paulo - FEA-USP. Professor at University of São Paulo - FEA-USP. E-mail: lucianereginato@usp.br.

https://orcid.org/0000-0003-1812-4311

2 Ph.D. in Accountancy from USP and Ph.D. in Education from University of Illinois at UrbanaChampaign (USA). Full Professor at University of São Paulo - FEA-USP. E-mail: edgardbc@usp.br.

https://orcid.org/0000-0002-0745-131X
} 


\section{CONSTRUINDO AVIÕES E APRENDENDO CUSTO PADRÃO: UMA ABORDAGEM FOCADA NO ALUNO}

\section{RESUMO}

Movido por um debate contínuo sobre a evolução da carreira em contabilidade gerencial e a influência de estratégias instrucionais sobre o desempenho dos estudantes, este estudo foca em estratégias de aprendizagem ativa em cursos de contabilidade gerencial. Com base na teoria de aprendizagem experiencial de Kolb, um quasi-experimento foi desenvolvido para avaliar o efeito de um caso prático supervisionado, em grupo e manipulativo, usando a construção de aviões para apoiar o ensino de custo padrão junto a estudantes de administração de empresas. Foram coletadas evidências de quatro turmas a partir de uma disciplina de contabilidade de custos em uma grande universidade pública de pesquisa no Brasil. Um total de 219 estudantes participaram do estudo. O professor ministrou aulas a todas as turmas sob condições idênticas em cursos semanais. Os dados foram tratados incluindo-se estatísticas descritivas, teste de amostras emparelhadas (hipótese experimental), e nuvem de palavras. Adicionalmente, especialistas (professores da área) validaram os resultados. Os achados são robustos (Cohen's d of 1.026) e indicam que o grupo experimental demostrou melhoria significativa no desempenho dos exames do pré e pós-teste, se comparado ao grupo de controle, com tamanho de efeito considerado grande. Contribuições do estudo focam em transferência de aprendizagem que favorecem os estudantes para a vida real e o desenvolvimento de habilidades sociais (o aluno constrói, interage e gerencia atividade trabalhando em times); experiência positiva que pode encorajar professores e administradores de programas ao uso de estratégias instrucionais mais ativas; e preparo dos estudantes para o mercado, desenvolvendo profissionais com habilidades de trabalho mais demandadas.

Palavras-chave: Custo Padrão. Metodologia Ativa. Educação.

\section{INTRODUCTION}

Accountants, as many other professions linked to business, must deal with the evolving nature of organizations and its processes. Accounting education has been called to change, more emphatically, in the past 30 years (Bedford Committee Report, 1986; French \& Coppage, 2000; Marhsall et al. 2012, Pincus et al. 2017), not only for the dynamics in its core content (e.g., IFRS), but especially with escalading concerns about instructional strategies to cope with our naturally evolving science and profession. Brewer et al. (2014) called the attention discussing the competency crisis in management accounting focusing on the skills gap: "the most pressing issued facing the profession." Studies on faculty skills (such as Marshall et al. 2012) tend to stress the problem and potential solutions from the faculty standpoint.

However, the education literature is also clear about the role of students and the relevance of experience. Dewey (1916, p. 163) stressed,

When we experience something we act upon it, we do something with it; then we suffer or undergo the consequences. We do something to the thing and then it does

72 Revista Contabilidade Vista \& Revista, ISSN 0103-734X, Universidade Federal de Minas Gerais, Belo Horizonte, v. 32, n. 1, p. 71-103, jan./abr. 2021 
something to us in return: such is the peculiar combination. The connection of these two phases of experience measures the fruitfulness or value of the experience.

An intrinsic relationship between the object and the subject naturally emerges from the experience, bringing a strong responsibility to the agent, in this case, the student: "mere activity does not constitute experience" (p. 163). Aldrich (2005), when discussing learning by doing and exploring simulations and other educational experiences, presented a shared assumption about students and how they are changing: "they are increasingly pragmatic. They crave interaction and personalization. They are highly visual. They are problem solvers. Often they are averse to reading. They want more material in less time... [and] they are computer-savvy" (p. xxix).

In these lines, active learning (Matherly \& Burney, 2013) and training (Silberman, 2006), when connected to the experiential learning framework (Kolb, 1984), represent relevant instructional approaches for accounting and management accounting. Knowles et al. (2005) highlighted such condition even more in adulthood. Batista (2004) relied on this approach in the Brazilian context, with cohorts of business administration and accounting majors, when studying the effect of business games. However, this strategy is still not used to its full potential. Nganga et al. (2013) reported less than 10\% adoption of experiential learning strategies in accounting education.

On the brink of the new millennium, Maher (2000) analyzed 50 years of management accounting education (including new courses, textbooks, new topics) and expressed concern in terms of future demand of management accounting courses, due to mismatch between academia and the job market. It was about a changing career. He suggested that in order to tackle potential enrollment decline in this field, there was a need to change the way we teach management accounting: "we should not limit ourselves to observing and reporting practice to students. Our educational priorities should be to help students develop life-long problem-solving skills and to understand the organizational and societal context in which decisions are made" (p. 344).

Thomson (2013), exploring the Manpower Group Talent Shortage Survey, declared: "Management accountants who are limited to working with numbers and money are missing the boat." The Manpower study (2013) reveals that accountants are becoming harder to find and hire, reaching the fifth place in the ranking of their Talent Survey. Thomson (2013) suggests a solution when writing "they should be involved in non-monetary reporting and analysis (such as employee numbers, hours worked, and quantities of materials used), as well as considerations like employee morale, information technology, community and environmental effects, and brand image." There is a potential competency and expectation gap in this area, when it comes to management accountants.

The Institute of Management Accountants (2013) took action and recently launched a website (competencycrisis.org) to raise awareness, align potential solutions and tackle a drastic change in the field of accounting with focus on the role of management accountants who need, according to their study, improved knowledge, skills and attitude related to strategic decision making, risk analysis, financial reporting, internal controls, effective communication, and ethics. Special attention is given to colleges and universities that now "struggle to keep pace with the realities of the marketplace and deliver the competencies 
needed. The result is a skills gap between academia and business." In fact, there is potential career opportunity for students who are able to leverage properly this career momentum.

Decades ago, the Accounting Education Change Commission (1990) suggested that:

Students must be active participants in the learning process, not passive recipients of information. They should identify and solve unstructured problems that require use of multiple information sources. Learning by doing should be emphasized. Working in groups should be encouraged. Creative use of technology is essential.

Based on the argument of student-centered learning environments and active learning instructional methods catalyzed by Kolb's experiential learning approach (Kolb, 1984), this study is set to explore the following research question: To what extent does the introduction of a guided team-based hands-on aviation manufacturing case improve the learning process related to standard cost? In order to tackle this question, we reviewed relevant literature in the field of accounting education, designed a teaching intervention (aviation manufacturing case) and developed a quasi-experiment in a real teaching environment, over the course of three years (from 2015 to 2017), with four cohorts.

The main reason for the study comes from multiple sources in the literature that emphasize the need, still unfulfilled, in management accounting education for more empirical studies, based on sound research design, to evaluate the effectiveness of optional curricular models and instructional approaches (Stout, Rebele \& Howard, 2006; Watson et al., 2007). Studies of this nature have received more and more attention from academics in recent years, and the present study, in particular, aims at filling a gap that still exists, related to the application of more active and student-centered approaches.

In light of these elements, the purpose of this study is to support the teaching and learning process, pointing out an active methodology that showed a positive result. Faculty members may be inspired to teach, not only standard costing, but other subjects related to the accounting area through the construction of student-centered knowledge. In addition, academic programs and, perhaps, higher educational institutions, may welcome some encouragement based on this research to reflect on methodologies present in their curriculum. This can somehow improve students' motivation and the quality of learning.

\section{LITERATURE REVIEW}

This section combines selected elements of accounting education literature, highlighting issues that involve the need to develop new skills, practices and curricular models, as well as concepts about the organizational environment when dealing with management accounting.

\subsection{Accounting Education: Integrating Content and Format}

The future of accounting as a branch of research and as a field of 
practice has been focus of several studies in the past, including those sponsored by relevant organizations across the globe (e.g., IFAC, IAESB, IAAER, AACSB, EAA, AAA, IMA, ACCA, ISAR/UNCTAD, NASBA), and still is. They not only have been expressing concern with the technical portions of the accounting education, but even more with additional set of skills that are highly demanded by the job market. An example is the AICPA Core Competencies (2011) with a set of skills (i.e., communication and leadership, strategic and critical thinking, focus on customer, client and market, information interpretation, technology) not directly related to the traditional accounting curriculum approach.

With a fair participation of representatives from countries all over the world, the International Federation of Accountants (IFAC), the International Accounting Education Standards Board (IAESB), and the Intergovernmental Working Group of Experts on International Standards of Accounting and Reporting (UNCTAD/ISAR), at distinct moments in history, supported specific curriculum guidelines for the accounting programs. The ISAR Model Curriculum (UNCTAD, 2011) is an example of the traditional focus on content, as guidelines to strong capacity building. The IAESB (2019) adopted a different approach, a competency model, when setting standards with a focus on reducing international differences and enhancing global mobility. This is an important action as the IFAC member bodies are those authorities with the credential-granting power.

Additionally, independent global research on this topic has been conducted, and the work of the Global Accountability Development Institute (GADI), known as the Global Accountability Transparency Index (GATI) is noteworthy. Karreman (2013) reports comparative results from countries around the world, focusing on the competency model (based on eight pillars of interest), assessing the quality of accounting education.

In academia, many studies explore a set of dimensions claiming for attention and action in accounting education. Typically, although concerned about the market-academia gap (Broome \& Morris, 2005; Salem, 2013; Siegel et al., 2010; Watson et al., 2007), scholars also focus on instructional strategies. An example is the review developed by Salem (2013) highlighting: (a) course content and curricula, (b) technology, (c) faculty development, (d) strategic direction, (e) program evaluation, (f) curriculum and course content, and (g) pedagogy.

It is paramount to stress the fact that most discussions consider accounting education in general, or more biased towards public accountants. The literature on education focusing on nonpublic accounting or industry specific needs do exist, but are minimal. This may be due to the incorrect and unfair assumption about the number of interested users. Siegel et al. (2010) are clear in stressing this point when entertaining the question "Is the current accounting curriculum appropriate for careers in industry and other nonpublic accounting paths?" (p. 45). They advance and highlight the trend of decreasing demand for transactional skills and increasing demand for decision support and performance management activities.

Maher (2000) when developing a critical analysis on the perspectives for management accounting in the new millennium addresses his own management accounting teaching experience adopting cases and experiential learning to the possible extent. He also emphasizes that computations should not 
be the end goal:

...the study of $A B C, B S C, E V A \circledast$ and similar concepts should not be primarily about making computations. The primary objective in studying these concepts should be about understanding the organizational issues that created a need for implementing such concepts and the prospects for their success or failure in light of the organizations environment (p. 343).

As a result of a joint effort between Management Accounting Section of the American Accounting Association (MAS/AAA) and the Institute of Management Accountants (IMA) a competency-based framework for accounting education (Lawson et al. 2015) is proposed, going beyond the typical public accounting focus, with three categories: Foundational, Accounting and Broad Management competencies. Specific elements of all three categories were influential to the design of the in-class activity adopted in this study (to be detailed in the Method section).

Based on this, it is evident the importance of teaching accounting in a systemic way, so that students can develop new skills, competencies, critical thinking, and ability to perform, practices that allow them to act efficiently in their work environments, as problem solvers. Next, challenges for accounting higher education are discussed.

\subsection{Challenges for Accounting and Higher Education Trends}

On the brink of a deep revolution in education (catalyzed by the Covid-19 pandemic), or as put by Christensen (2008) "customized learning in studentcentric classrooms" (p. 38), education is facing a disruptive experience: one that plays with dimensions such as funding, student and faculty engagement and reward, competency-based model, societal needs, generations, gender, technology, professional lifecycle, and work-life balance (Ciulla, 2000; Dimitrios et al. 2010; Rifkin, 1995; Selingo, 2013; Way, 2013). Such disruptive moment should not pass by unnoticed especially with potential consequences on relevance loss for both academia and professions as currently known. Around the world we can single out initiatives, in accounting, trying to anticipate ways of overcoming challenges and taking advantage of opportunities long before this new environment, such as described by Lin and Hunter (1992) and Pincus et al. (2017).

We selected relevant topics, from the education literature, to explore in this section: student-centered, andragogy, peer learning, cooperative learning, teamwork, interpersonal skills, organization skills, deep learning and experiential learning. They are all interconnected and, together, they represent the foundation of the experiment designed and evaluated in this study.

Systematically, the departure from instructor-centered teaching to student-centered learning is gaining more attention from educators in many areas, mainly in fields where critical thinking is vital to empower minds and enable new strategies. That is the case in accounting, as clearly stressed by the AAA Pathways Commission (2012) when rethinking the next generation of accountants.

From pedagogical models, the fields of Education and Human Resource Development fostered the development of andragogy, where adult learners 
tend to exhibit less dependence. As stated by Knowles (1970, 1980), a key andragogical assumption is that adult learners bring a distinct set of learning conditions (i.e., self-responsibility, self-direction, life experience, readiness to learn in order to evolve and effectively cope with changing life tasks and problems, and internal needs to grow towards self-fulfillment).

Another important piece in higher education is not always part of the traditional teaching model: learning from fellow students. In a world of MOOCs (Massive Open Online Courses), peer learning is critical, and participants tend to adapt quickly, developing beyond the traditional outcomes, by helping others: it is an opportunity for developing higher order skills (e.g., evaluating work of others). Moving outside one's comfort zone may be challenge at first, however if well planned and supported it tends to be very rewarding (Lim et al. 2014).

Learning is a social and experience-based activity, and as stated by Bandura, "in the social learning system, new patterns of behavior can be acquired through direct experience or by observing the behavior of others" (1971, p. 3). Following this idea, Slavin (1980), in a seminal work, reviewed 28 field projects adopting the cooperative learning model and found positive outcomes in student achievement, self-esteem, and in several other dimensions. Cooperative learning is natural and can be perceived as a positive experience affecting skills such as teamwork, self-management, and planning and organizing (Dyball et al., 2007). Sathe (2009), analyzing small group performance, also found positive effects on interpersonal skills and teamwork. Considering the skill set to empower students for higher learning performance by taking advantage of this learning model, Ballantine and Larres (2007) found positive influence on student planning and organization skills. In accounting, Lancaster and Strand (2001) evaluated the existing relevant literature on team-learning and suggested positive outcomes. They also conducted a pretest posttest control group experiment (with a total of 163 participants), however they accepted validity treats (use of cooperative learning elements in the control group as well) to justify no significant effect in a managerial accounting course.

The deep- and surface-approaches to learning are very present in the education literature, bringing important explanations to elements the are very relevant in accounting education, such as critical thinking, meaning, personal experience (Duff, 2014; Duff \& McKinstry, 2007). An example is the study conducted by Phillips \& Graeff (2014) who assessed the effect of in-class simulation (i.e., buying and selling products) to bring a hands-on approach when teaching first year accounting. They relied on active learning (case method, peer learning groups and simulations) to assess pretest and posttest attitude and understanding. In all measures, positive outcomes from the deep-surface approach were found.

\subsection{Experience and Kolb's Experiential Learning Theory}

Mostly in higher education, the idea of constructing meaning of elements, processes and interactions is well regarded. Theorists like Candy, Dewey, Lave, Lewin, Piaget, Rogoff, and Vygotsky can be cited for their work on constructivism, which is related to the construction of knowledge and meaning by experience or "how people make sense of their experience" (Merriam \& Caffarella, 1999, p. 261). 
Kolb, influencing many studies in business and accounting education, is a key theorist in this area of experiential learning. For him, learning is "the process whereby knowledge is created through the transformation of experience" (1984, p. 38). As discussed by Cornacchione (2004), when describing learning theories with relevance to accounting education, Kolb was clearly "influenced by ideas from Dewey (learning and experience), Lewin (being active when learning) and Piaget (intelligence is related to the interaction with the environment)." (p. 81). In fact, Kolb (1984) discusses Lewin's action research model, Dewey's model of learning, and Piaget's model of learning and cognitive development. Piaget's model, explicitly related to the student's age, suggests four stages: (a) concrete phenomenalism, (b) internalized reflection, (c) abstract constructionism, and (d) active egocentrism.

Kolb's proposed model has four main phases that are connected to Piaget's model: (a) concrete experience (engagement), (b) reflective observation (thinking about the experience), (c) abstract conceptualization (generalization or principles) and (d) active experimentation (testing what was learned). The key idea is that "learning involves transactions between the person and the environment" (Kolb, 1984, p. 34) and, for the learner, "experience is translated into concepts, which, in turn, are used as guides in the choice of new experience" (Kolb, 1984, p. 31). Experience is central and the order of the phases is relevant according to the nature of the experience and the learning goals.

Concerned about unguided applications of certain instructional approaches, Kirschner et al. (2006) emphasizes the need for guidance based on the human cognitive architecture (they critique unguided applications of instructional approaches such as constructivist, discovery, problem-based, experiential and inquiry-based teaching). This only stresses the need for training and orientation to prepare all participants, such as faculty and students. Implementing experiential learning activities, for instance, should not go unplanned, but carefully organized portion of the teaching and learning process, part of an institutional development process as prescribed by Kolb \& Kolb (2005).

Hassall \& Joyce (2014, p. 377) evaluate "the potential for the use of experiential learning as a solution to the pedagogic problems" in accounting education, mainly related to the traditional chalk-and-talk instructor-centered models. Reflecting on several studies and models, they frame learning as an action of the learner, therefore, student-centered and meaningful may emerge.

Experiential learning can be implemented in a single activity or take a whole program into a new dimension, or something as study tours (Webb, De Lange, \& O'Connell, 2009). This is particularly true in accounting where the potential of first-hand experiences when visiting organizations and professionals is enormous. As with the positive learning outcomes reported by Dellaportas \& Hassall (2013), after adopting Kolb's experiential learning model to design a prision visit and take their students there.

But, experiential learning can be adopted with well crafted instructional cases, where real-world simplifications are in parallel with expanded classrooms opportunities, even more now with access to a wide range of resources via technology. As an example, Batista (2004) developed a study based on Kolb's model and a business game intervention with 55 business and accounting majors, finding positive academic outcomes. Vinciguerra \& Lafond (2011) 
present a typical example of hands-on intervention to teach managerial accounting. In their study, students working in teams learn cost accounting concepts while dealing with manufacturing process of two products and the full range of costs concerns, including identification, classification, and product costing. Stewart \& Dougherty (1993) developed an instructional case intervention, as an experiential learning activity, in a cost accounting course, with positive outcomes.

Pimentel (2007) emphasizes the clear link between Kolb's experiential learning and several dimensions of professional development. She emphasizes the relevance of the dynamic nature of the learning process and the suitability of experience, what is even more aligned with professional areas such as accounting. The relevant literature shows concern about undergraduate education, but as Villardi \& Vergara (2011) states, there are implications of experiential learning for graduate programs as well, especially in the business area.

Several studies aim at Kolb's learning style inventory, a more specific dimension (instrument) of his theory. There is a vast amount of literature based on surveys to identify learning styles. That is the case of Santos et al. (2014), who identified learning styles of accounting majors from a public university. Sonaglio et al. (2012) explored Kolb's LSI with a sample of 187 business majors, just after the discussion of a case study. They found an influence of the intervention (a case study) on the skill set of the participants, with evidence from distinct types of skills according to their learning style.

In similar lines of competency development and its interaction with learning styles, Schmitz et al. (2013) discussed the role of experiential learning, based on Kolb's framework, in a project management course with business majors. Relying on focus group, they gathered data from three sessions with 10 participants each. Leadership and communication skills were most influenced by the approach. Reis et al. (2012) analyzed data from 402 accounting majors using Kolb's framework and found $48 \%$ of convergers. Leite Filho et al. (2008) found dominant learning style (divergers) in a sample of 52 accounting majors. Valente et al. (2008) after analyzing results from 110 college students, found active experimentation (44\%) as the dominant style. Working with 114 students in finance, Cordeiro \& Silva (2011) relied on Kolb's framework to find the effect of learning styles on academic performance in this field. However, they could only find an interaction between professional experience and learning styles.

\subsection{Experiential Learning and Managerial Accounting}

While we observe recent changes of managerial accounting in the accounting education literature (Apostolou et al., 2001, 2010, 2013, 2018), we can see a decrease pattern in managerial accounting publications in top-level academic journals (Merchant, 2010). This dynamic is interesting, since there is a call for narrowing the gap between academia and practice, with effects not only on financial accounting, but also managerial accounting (AAA, 2012). There is also a claim about how management accountants outnumber those working externally and a significant rise of management accountants, as presented by Sorensen (2009, p. 1271), based on data from the US Bureau of Labor Statistics: "in 2005, $85 \%$ of the accountancy profession works inside organizations as 
accounting professionals and $15 \%$ of the profession works externally and performs public accounting services." Beyond these numbers, Sorensen goes on stressing the need to fine-tune the accounting curriculum to match the anticipated business needs for management accountants. Schiller (2010) presents an interesting example with practical implications. In this line, more experiential learning seems to be a natural instructional strategy to help fulfill these needs. Butler et al. (2019) stress the benefits of experiential learning to critical thinking and problem-solving, both well connected to managerial accounting.

An example of organized teaching approach aiming at experiential learning in management accounting comes from Spraakman \& Jackling (2014). Acknowledging the critique developed by Kirschner et al. (2006), Spraakman \& Jackling (2014) revisited Schoenfeld's framework for mathematics and discussed a conceptual framework for learning management accounting, building on problem-based learning and instructional cases. The four-part framework consists of (a) resources (inventory of facts and procedures), (b) heuristics (techniques), (c) control (matching heuristics with the problems for solving), and (d) belief systems (world views). This approach facilitates actions to prepare faculty and students for the experience, while creating better conditions to build more authentic learning experiences, as discussed by Clark, Threeton \& Ewing (2010) when analyzing career and technical education and Nooghabi, Iravani \& Fami (2011) who evaluated experiential learning challenges in agricultural colleges.

Borges et al. (2014) adopted the theory of procrastination to explain the $47 \%$ lack of dedication and disinterest of students who failed a cost accounting course. This study presents a potential example of consequences of the mismatch between course design and student expectations and motivations. This ideal matching was exactly what Bollen, Janssen \& Gijselaers (2002) focused when assessing the effects of innovations in teaching methods. They found that such course design improved both declarative and procedural knowledge of accounting majors.

If well adopted, instructional cases are good examples toward more experiential learning strategies (Stout 1996). In managerial accounting cases also seem to be more natural as the decisions to be supported intrinsically allows for more than one structured response. That is the case of "Dilka Plastic Products Company," proposed by Herath (2006) and "Custom Fabric Ventures," proposed by Braun (2013), both successful (with positive academic outcomes) cost accounting instructional cases. Braun (2013) adopted the flipped classroom model with a goal in mind: "to maintain a sense of realism and challenge students to think beyond simple mechanics" (p. 411). Students perceive themselves as central in the process, receiving the right amount of guidance to perform and learn. These examples may be compared with more traditional approaches in cost accounting, that are absolutely fine, however based on a different educational frame of reference, as the case of textbook-based approach (Mister, 1983; Pollard, 1986).

\section{METHOD}

\subsection{Study Type}

The research question of this study drives this quasi-experimental design, 
based on Gall, Gall, \& Borg (2003) approach. Thus, this is a quantitative study aiming at assessing causal effects of specific treatment (in-class hands-on teambased case of manufacturing planes) to support standard costing learning. In addition, according to Luft \& Shields (2003), causal effects in management accounting education should drive research designs.

We adopted a pretest-posttest control-group design, which is robust and mitigates sources of internal invalidity while, according to Gall, Gall, \& Borg (2003, p. 385) singling out "the interaction of testing and X (treatment)" as a concern about external validity. The design sensitivity of this study is based on Lipsey and Hurley (1997), targeting an effect size of 0.5, statistical power of .95, and assuming a sample size of at least 105 observations in each of the treatment and control groups.

\subsection{Study Hypothesis}

Burch et al. (2014), based on a relevant meta-analysis of 40 years of academic research on experiential learning, found an overall "significant positive improvement in the means of the experiential learning groups over the control groups" (p. 281). They showed a standard difference in means of .75 ( $p<.01)$, based on a random effects model. Stewart \& Dougherty (1993) developed a quasi-experimental study to evaluate the effect of case studies in cost accounting and found significantly higher academic performance of the experimental group $(t(59)=1.90, p<.05)$.

Kolb's experiential learning theory (1984) and a large number of empirical studies (relevant literature review) are signaling the direction of the effect, and the study of Burch et al. (2014) suggests an effect size. Thus, for this study the main hypothesis is set as following:

$\mathrm{H}_{l}$ : Students who experience guided in-class team-based first-hand manufacturing process present significantly higher scores when tested on standard costing.

This hypothesis is tested in this pretest-posttest control-group design, and we expect a significant increase (assuming the aforementioned .75 effect size from the literature) in scores of the experimental group when compared to the group baseline (pretest) and to the posttest results of the control group.

\subsection{Sample and Intervention}

The empirical data for this study came from cohorts of a large public research university in Brazil. We designed this pretest-posttest quasi-experimental study with control and experimental groups, all taught by the same instructor with the same syllabus (textbook, class sequence, content, exercises and activities). The only difference, in this case the treatment, was the aviation manufacturing case (AMC). Having the same instructor was key, so we could control for validity threats with careful follow up by the instructor during the entire semester.

The sample derived from existing groups (formal intact classes), not randomized selection, with the treatment occurring in 2017. The control group involved business administration freshmen students from two cohorts (morning 
and evening) who took the course in 2015. In 2017, two cohorts (morning and evening) of freshmen students from business administration were also part of the study, as the experimental group. The two-year separation was due to program administration planning. With this design we targeted the effect of the intervention on learning outcomes related to standard costs.

Both pre- and post-tests involved standard costing (direct and indirect costs) and were the same for all cohorts, aimed at greater comparability of results. The pretest involved computation of standard and actual figures followed by related variations. After variations were computed, students focused on analyzing favorable and unfavorable variations according to the organization, with an open in-class discussion about potential decisions and actions based on each scenario.

In the posttest, students were asked to compute (a) indirect standard costs, (b) volume variation, and (c) indirect manufacturing costs variation. There is a natural additional complexity in the posttest. The instructor marked both tests, using the same rubric, on a 100-point scale.

\subsection{Research Protocol}

In all cohorts, the subject of standard cost, related concepts, activities, and pre- and post-tests were developed during weeks 12 and 13 (in a typical 15week semester). These two sessions were well aligned with the cost accounting syllabus and the previous topics.

The experiment was designed having in mind the fact that the students were all business administration majors, freshmen, and decision-making was stimulating for them. As we could relate cost accounting to their decision-making thinking, a natural interest was created. A manufacturing case was designed, in this case it was about building planes, during class time and in small teams, with simple materials provided by the instructor. The instructor proposed the standards (direct and indirect costs, and manufacturing time) and during the activity, students were able to record their performance, including time and outcomes of the bidding process, affecting costs. The end goal was to enable students to understand the variations between planned and actual performance.

The intervention was designed with three phases: (a) before, (b) during, and (c) after the manufacturing activity. We now summarize each phase.

\subsection{Procedures Before the Activity}

Based on the existing syllabus, the two sessions devoted to standard costs were adapted to hold the intervention (activity), including in-class team manufacturing, reflection, and discussion of concepts and results, as well as time for taking both pre and post tests. A research on the product to be manufactured was carried out, controlling for required resources and task simplicity, including appropriate fidelity levels for concepts and activities such as raw materials, labor, and indirect costs. After considerations, we decided about the mini wooden handcraft planes as the product to be manufactured. Considering previous experience with interviewed local artisans and available materials on the Internet, we decided about the resources to be used and 
estimated the initial figures for the activity. Table 1 shows a summary of these elements:

\section{Table 1}

Cost details of the activity

\begin{tabular}{l|l}
\hline Cost Items & Unit Price $(\$)$ \\
\hline $\begin{array}{l}\text { Wooden Clothespin } \\
\left.\text { (per purchasing batch, } \mathrm{B}_{\mathrm{x}}\right)\end{array}$ & $\mathrm{B}_{1}=0.17 ; \mathrm{B}_{2}=0.20 ; \mathrm{B}_{3}=0.18 ; \mathrm{B}_{4}=0.19$ \\
Wooden ice-cream stick & $\mathrm{B}_{1}=0.04 ; \mathrm{B}_{2}=0.03$ \\
(per purchasing batch, $\left.\mathrm{B}_{\mathrm{x}}\right)$ & \\
Wood glue & 0.26 \\
Small color pens & 0.03 \\
Large color pens & 0.05 \\
Indirect costs $\left({ }^{*}\right)$ & 0.78 \\
Direct labor costs $\left({ }^{* *}\right)$ & 0.22 \\
\hline
\end{tabular}

Source: built by the authors.

$\left(^{*}\right)$ Indirect costs involved rental, insurance, electricity, depreciation (scissors cost), all previously computed by the instructor based on estimated values to make sense in this activity.

$\left({ }^{* *}\right)$ Direct labor costs were computed based on existing market research (Catho, 2018) for a worker in this manufacturing job, considering an the legal environment of the region. Computing this cost per minute involved times and movements records to establish the standard manufacturing time to generate one mini wooden handcrafted plane (based on a similar process from an experienced artisan). The standard time to manufacture one plane was 1 minute and 50 seconds, and the value was based on a wage of $\$ 1,533.50$ with 220 manufacturing hours per month.

The activity involved providing teams with the required resources, based on different batches with distinct costs. The instructor controlled the distribution and respective costs for each team. This was a simple solution so teams would experience different costs and final cost figures. For each cohort we used four batches of wooden clothespin and two batches of wooden ice-cream sticks (adding up to 96 clothespin and 176 sticks), 33 colored pens (both small and large), 11 tubes of glue, and 11 scissors. In case of destruction of any materials, there was an immediate reposition free of charge.

We provided students with a handout and forms. The handout contained detailed instructions about the activity, divided into (a) planning (e.g., team organization, manufacturing process, and organization name), (b) development (e.g., resources, costs, and timing the process), and (c) control (actual cost computation, variations, and discussion). The forms were a valuable resource as students could think about the issue at hand and record their decisions, with certain guidance, as the activity was happening.

Next, we present details of the projected standard cost per unit (\$1.54) used by the instructor to support the activity. In this example we selected specific batches of clothespin and sticks: clothespin $(\$ 0.17)$, stick $(\$ 0.03)$, glve $(\$ 0.26)$, small color pen (\$0.03), large color pen $(\$ 0.05)$, direct labor for 1 minute and 50 
seconds $(\$ 0.22 ; \$ 1533.50$ per month / 200 hours $=\$ 6.97$ per hour $/ 60$ minutes $=\$$ 0.12 per minute, plus $\$ 0.10$ per 50 seconds), indirect costs $(\$ 0.78)$.

\subsection{Procedures During the Activity}

The class was divided into small teams with 4 to 6 students, and the resources distributed to the teams. The teams were free to decide about the manufacturing process (e.g., serial or order production), and this was perceived by them as a key element in reasoning about both manufacturing performance and cost efficiency. As business administration majors, this freedom was well taken by students in terms of organization design and managerial approach.

Each group received 3 small color pens, 3 large color pens, 5 wooden clothespin, 16 ice-cream sticks, 1 tube of glue, and 1 scissor. The instructor distributed, to each team, a model of the end product (mini wooden handcraft plane), before they started the manufacturing process. The process involved assembling the parts and coloring (painting) the planes. The activity took 2 hours in the morning cohort and 2 hours and 30 minutes in the evening cohort. This time considered planning, manufacturing, data collection, computing results, and comparing the results against the standard cost.

\subsection{Procedures After the Activity}

One week later, the second session was used to host the discussion about the activity and standard cost concepts, based on extra-class assigned reading (after the hands-on experience). Just after a brief introduction led by the instructor about concepts and outcomes of the activity, a large discussion was held with intense participation of students. After the discussion, students took the posttest, which consisted of two integrated exercises (one targeting direct costs and the other on indirect costs).

With unanimous consent of participating students, all planes created in this activity were donated to a local church in charge of distributing to children during Christmas time.

\subsection{Validation of results}

In order to validate the results in relation to the use of this type of instructional methodology (active learning) by other faculty members, we elaborated open questions that were used in interviews with professors, experts in this field. The profile of this group of experts can be built with, the information included in Table 2. 
Table 2

Expert Group

\begin{tabular}{c|l}
\hline Interviewed & \multicolumn{1}{c}{ Academic and professional Information } \\
\hline A & $\begin{array}{l}\text { Professor with } 25 \text { years of experience in higher education, master's and } \\
\text { doctorate in accounting and controllership and doctorate in education. In } \\
\text { addition, the professor works in companies in various segments }\end{array}$ \\
\hline B & $\begin{array}{l}\text { Professor with } 20 \text { years of experience in higher and technical secondary } \\
\text { education, master's degree in accounting sciences and doctorate in } \\
\text { administration. Also, the professor worked in the administration of the } \\
\text { University }\end{array}$ \\
\hline C & $\begin{array}{l}\text { Professor with 13 years of experience in higher education, master's and } \\
\text { doctorate in accounting and complementary training in education } \\
\text { methodologies }\end{array}$ \\
\hline D & $\begin{array}{l}\text { Professor with 10 years of experience in higher education in Brazilian and } \\
\text { foreign institutions, master's degree in accounting sciences, doctorate in } \\
\text { accounting and controllership and in business abroad }\end{array}$ \\
\hline E & $\begin{array}{l}\text { Professor with 8 years of experience in higher education, master's degree in } \\
\text { economics, doctorate in accounting and controllership and specialization } \\
\text { in education - active methodologies }\end{array}$ \\
\hline
\end{tabular}

Source: prepared by the authors.

The interviews were conducted in the beginning of 2019 and involved faculty members at different universities (four in Brazil and one in France).

The designed questions had the goal of addressing: (a) opinion on the use of active learning methods, such as the one adopted in the subject of cost accounting; (b) advantages of the adopted approach; (c) disadvantages of the adopted approach, and (d) insights about active learning methods and/or this method, in particular.

The selected interviewees were briefed and invited to participate. Just after their agreement, both a summary of the intervention and a set of questions were sent to their respective electronic addresses, so that they had contact with the topic and the script. The responses were asked to be returned in written format and individual follow-up interviews, in-person or by phone, were scheduled for clarifications. It took three months to finalize this process and data collected were treated using Wordclouds (2019), which enabled us to highlight the most used and important words for our study.

\section{DATA ANALYSIS AND FINDINGS}

\subsection{Descriptive Statistics and Paired Comparisons}

A total of 219 freshmen students, all business administration majors from a large research public university in Brazil, participated in this study after abiding by an informed consent, during their cost accounting course. The control group was made of the evening (49\%) and morning cohorts of 2015, with a total of 109 students, while the experimental group was made of the evening (55\%) and morning cohorts of 2017, with 110 students. Gender was also balanced, with a slight majority of male students for both control (61\%) and experimental (56\%) groups.

A paired-samples t-test was conducted to compare the pre- and posttests of both groups assessing the effect of the aviation manufacturing case in 
the experimental group and test the hypothesis of this study (Students who experience guided in-class team-based first-hand manufacturing process present significantly higher scores when tested on standard costing). There was a significant difference in the academic performance scores in both groups (see Table 3). For the control group, the pretest scores $(M=85.51, S D=8.376)$ were significantly higher than the post-scores $(M=71.06, S D=13.926): t(108)=10.107, p=$ 0.000. For the experimental group, students exposed to the aviation manufacturing case, the pretest scores $(M=77.75, S D=9.379)$ were significantly lower than the posttest scores $(M=82.71, S D=7.966): t(109)=-6.948, p=0.000$. With these results the set hypothesis is supported, as the post-test score of the experimental group is higher (statistically significant at the .01 alpha level) than the pre-test.

Table 3

Pre- and post-test performance

\begin{tabular}{l|c|c|c|c|c}
\hline & & \multicolumn{2}{|c|}{ Pre-test } & \multicolumn{2}{c}{ Post-test } \\
\hline & $\mathrm{n}$ & Mean & Std.Dev. & Mean & Std. Dev. \\
\hline $\begin{array}{l}\text { Control } \\
\text { Group }\end{array}$ & 109 & 85.51 & 8.376 & 71.06 & 13.926 \\
\hline $\begin{array}{l}\text { Experimental } \\
\text { Group }\end{array}$ & 110 & 77.75 & 9.379 & 82.71 & 7.966 \\
\hline
\end{tabular}

Source: built by the authors.

Thus, as observed, the control group experienced a decline from pretest scores, whether the experimental group experienced an improvement. This effect is represented in Graph 1.

\section{Graph 1}

Pre- and post-test performance

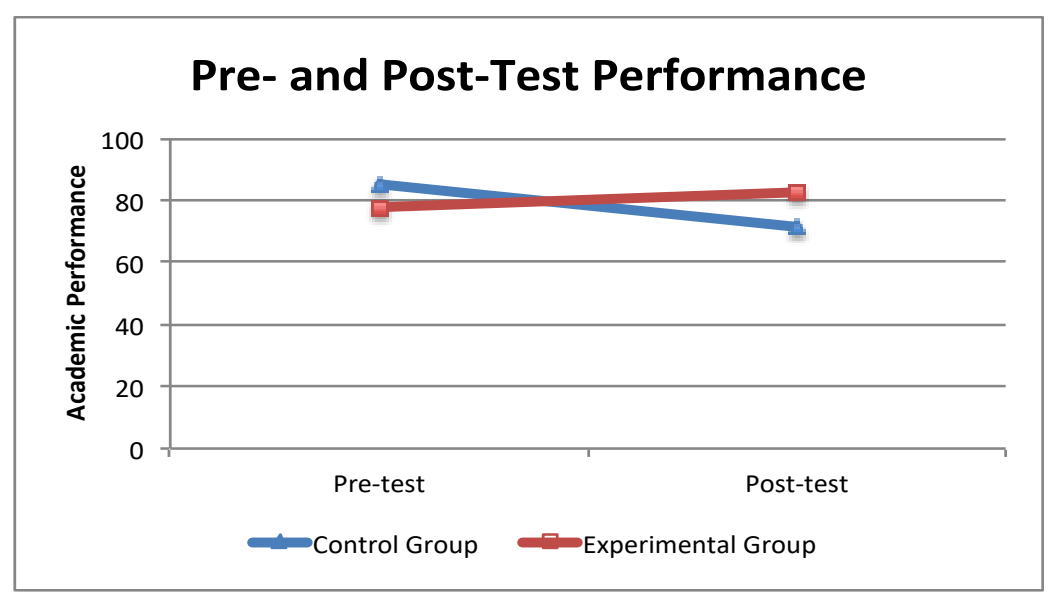

Source: prepared by the authors.

The Cohen's $d$ in this study is 1.026, based on the post-test measures and pooled standard deviation, with robust enough results to be claimed according to the set study design sensitivity. This can be considered a large effect size with implications for accounting education, especially the adoption of similar teaching cases in light of Kolb's experiential learning model. 


\subsection{Overall Analysis of the Intervention}

As a relevant part of the description of our sample, we share our overall perception about participating students. All cohorts participating in this study demonstrated interest and commitment to the topic of cost accounting. This is particularly important to stress, since they are all business majors (freshmen). The 2015 cohorts were particularly more engaged, even more in the morning cohort. After teaching all cohorts it is possible to state about high level of group comparability, especially considering the presence of both morning and evening cohorts in both groups.

Students' self-organization challenges were more apparent in the 2017 cohorts, even more in the morning cohort, when compared to the 2015 cohorts. The 2017 morning cohort complained more about competing tasks (i.e., activities from other courses, competing exams, study organization). Evidence for this perception came out of typical interaction with students and natural instructor activities, unveiling differences in attention during lectures, in-class participation, types of questions raised, use of office hours (both instructor and teaching assistants), and development of extra-class exercises.

Next, some direct quotes from students $\left(S_{w}\right)$ after the interventions help grasping the environment and context of the activity:

"I will be 45 and will remember this activity" $\left(S_{a}\right)$

"Great! I haven't done this since childhood" $\left(S_{b}\right)$

"We loved the activity; it's different and we should do this more often" ( $\left.S_{c}\right)$

"We are loving it" $\left(S_{d}\right)$

"Our planes are the best in the market" $\left(\mathrm{S}_{\mathrm{e}}\right)$

"Our plane is worth more, it carries our creativity and engagement" $\left(\mathrm{S}_{\mathrm{f}}\right)$

"We loved the idea of donating our planes to children, let's do our best" $\left(S_{g}\right)$

We can tell from these sample quotes about their engagement level and commitment to the activity. This drive represents appropriate conditions for learning and is part of the active learning framework (Matherly \& Burney, 2013; Silberman, 2006).

In general, teams enjoyed the activity. At first, the reaction was a surprise: students did not believe we were about to conduct such an activity in class. They seemed to be expecting a typical case, in their words, to be analyzed in class. Students expressed excitement when understanding the activity and its hands-on approach.

During the activity all teams planned their work before starting it, with each team ending up with very distinct organization format in terms of labor and manufacturing process. Most of the teams shared tasks. In general, tasks involved assembling, bonding, and painting (coloring). Typically, one in each team was in charge of timing manufacturing process of each plane. In some cases, the student in charge of timing was also engaged in the assembling process. Also, in each team, one student was selected to act to obtain the resources from the instructor (organized in batches).

After all the steps involved in the actual manufacturing process (see 
Picture 1), teams analyzed their numbers, paying attention to the comparison between actual versus standard costs (given by the instructor). With the maturing internal discussion, teams gathered as a whole class to share their experience, including their numbers.

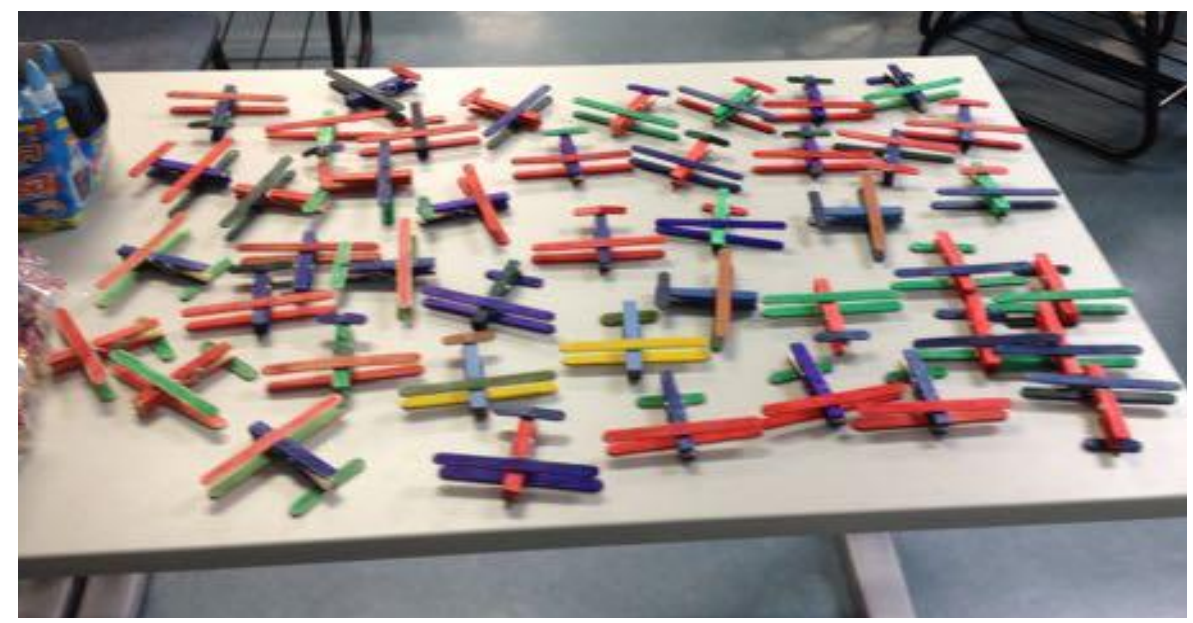

Picture 1 - Manufactured planes.

Source: prepared by the authors.

Each team presented its own performance to the entire class and we could observe a large dispersion across them. For example, the manufacturing process for just one plane ranged from 1 minute and 40 seconds (less than the given standard) up to 14 minutes. The class entertained several reasons for such variation, since it was the first time they learned about the performance of their peers. During the discussion, the most relevant reason to explain such variation was the production process itself. The main conclusion among all groups identified the labor component (sequence and individual differences) as the critical piece explaining most variations in productivity. It was an eye-opening moment and a teaching opportunity, related to lessons learned in this process.

\subsection{Analysis of the Validation of Results}

Considering the answers of the interviewees, all were in favor of applying active methodologies to improve student learning.

When addressing the opinions about the methodology used in this study, emphasizing the advantages of its use, the experts unanimously affirmed that there is an important link between theory and practice. According to one of the interviewees, "In cost subject, for example, this methodology allows the student to relate basic concepts such as identification and classification to more advanced concepts such as the application of costing methods. Project learning, one of the modalities of the active methodology, allows the student to interact with the process of identifying costs (product and services) and realizes the importance of applying specific costing methods for managerial analysis and for legal assistance".

The highlights of the transcribed texts are exposed according to the figures that follow. 


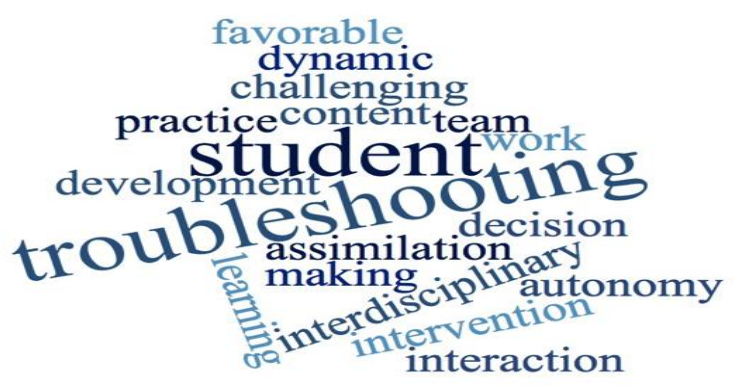

Figure 1 - Perceived advantages of the approach Source: prepared by the authors.

Among the advantages of using this methodology, we identified the dynamic, interesting and engaging learning that awakens the student to seek solutions for problem solving, interest in completing readings, as well as asking the professor for support in the activity, collaborative learning process, and specific information about the applied concepts. It also highlights student autonomy in solving problems, as well as generating discussion of the topic in the group. This class application allows the association of interdisciplinary concepts, specifically in cost content, such as process management and financial controls.

Another important aspect of this methodology is teamwork, since it requires everyone to share learning, collaborate with each other, understand the difficulties of colleagues, and assume responsibility for their role or activity within the group. Furthermore, it stimulates decision-making, what is important for business leaders and company managers.

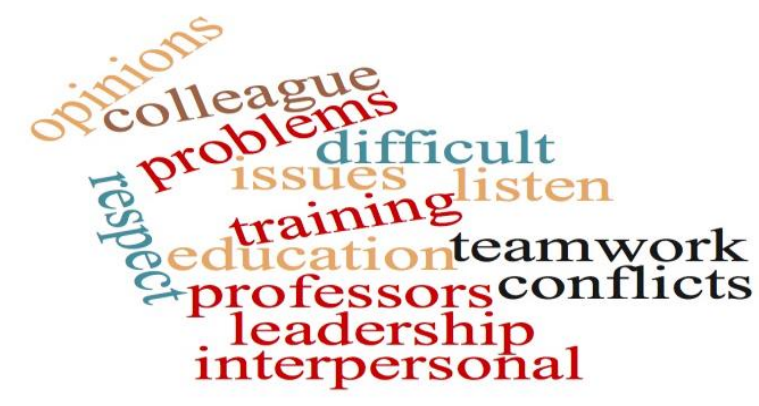

Figure 2 - Perceived disadvantages of the approach Source: prepared by the authors.

When dealing with disadvantages, the interviewees pointed out conflicts in teamwork and interpersonal relationships. This aspect appears in the application of active methodologies because collaboration is necessary, putting oneself in the other's place, respecting and listening to the opinions of the team members, as well as working on leadership issues.

In reality, the points presented deal with conflicts in human relations that must be included in the curriculum of the management courses, requiring 
qualified professionals in the subject. The professional when applying the active methodology in technical content often faces conflict situations in the group, and must be prepared or anticipate actions to solve this problem, which is not always easy to be solved.

Some opinions also emphasized that there are no disadvantages in the application of this methodology, students tend to learn and improve performance in the subject studied, as well as to develop the deficient skills.

\section{DISCUSSION OF THE FINDINGS}

As showed, the evidence supports the hypothesis of this study $\left(\mathrm{H}_{1}\right.$ : Students who experience guided in-class team-based first-hand manufacturing process present significantly higher scores when tested on standard costing), with a large effect size. This is a key finding that adds to the existing literature on experiential learning (mainly focused on Kolb's experiential learning theory) and expands the results of Burch et al. (2014). In addition to this, it is noteworthy the observed increased motivation of students in the experimental group.

The two-session intervention was designed to follow Kolb's model, starting with active experimentation. Students in the experimental group planned their actions in small teams, with proper guidance from the instructor. Next, the concrete experience was developed, which was the actual manufacturing of the planes. This was a very rich opportunity for self-awareness and peer interaction, as well as a moment to interact with resources and the instructor on an as-needed basis. These two stages were concluded in the first session. During the second session (one week later), we had the reflective observation when students were able to conduct a more organized review while thinking about the experience. The instructor then supported the final stage with a semi-structured approach to help students to develop an abstract conceptualization, by exploring the lessons learned during the entire activity. This final stage was critical since it provided for important links between the hands-on activity and the cost accounting concepts targeted in the course. This sequence demonstrated to be key for the experiment.

In 2015, the control group was able to learn the concepts and acquire the skills by only reading the textbook and solving exercises. Although all grades can be considered high (averages are above $71 \%$, see Table 2), the control group showed a decrease in their grades. This was expected, due to the proportionally increased complexity level of the posttest. On the other hand, the experimental group showed a significant improvement in their grades.

The intervention followed Knowles' andragogy model and the activity clearly presented a student-centered shift. Participating students noticed these approaches in the design. Moreover, elements of peer learning, cooperative learning, teamwork, interpersonal and organization skills (Ballantine \& McCourt Larres, 2007; Sathe, 2009), although not directly measured in this study, can be considered good side effects based on the perception of the students and faculty, during and after the implementation of the intervention. These skills are even more important for freshmen. The intervention was also an example of deep learning, with potential impacts on their future as students. 


\section{CONCLUSION}

Managerial accounting plays an important role in the transition faced by accounting both in academia and practice. This study revisited accounting education and managerial accounting while targeting a specific research question (to what extent does the introduction of a guided team-based handson aviation manufacturing case improve the learning process related to standard cost?). We found support to our experimental hypothesis (students who experience guided in-class team-based first-hand manufacturing process present significantly higher scores when tested on standard costing), which is aligned with relevant literature on experiential learning (adopting Kolb's model) and with the meta-analysis of experiential learning developed by Burch et al. (2014). In addition, based on the validation of the study results, the interviewees (all expert faculty members in the field) were unanimous in stating that the methodology used is advantageous and offers improved skills and promotes adequate learning conditions for students. An important contribution of this study, beyond adding to the relevant literature, is to signal faculty, program administrators, students, and employers about the feasibility and effectiveness of simple guided hands-on team-based experiential teaching approaches to help students reach educational objectives in managerial accounting.

Two key contributions for students are related to (a) transfer of learning, as the environment fidelity level in the activity tend to benefit a smoother transfer of standard costing set of knowledge, skills and attitude in real life situations and (b) soft skills development, as students had to deal with organization, planning, team-work, negotiation, time pressure, and quality while competing with other groups and learning as applying how and why managerial accounting and standard costing interfere in a manufacturing process. For academy an important contribution is the in-class activity itself and the reported experience. This is linked to the fact that, over the years, active instructional strategies have been receiving attention as a way of creating significant learning experiences that last longer as their impact on students tends to be stronger and meaningful. A contribution for program administrators is the effectiveness of instructional strategies that do not require significant extra resources, but training, attitude and support, with clear benefits for students while refreshing the educational approach of key subject areas. The actual case, results and experience behind this study represent a contribution for faculty members interested in knowing about new ways of designing parts of the courses, including active learning approach. For society, in general, and organizations, in particular, a relevant contribution of this study is connected with the meaningful active experience and students reported overall attitude with the in-class activity. Accountants with active learning experiences, with both hard and soft skills development, tend to better match organizational needs, creating a potential for performance improvement.

The simplifications for prices and quantities used in the activity and for standard costing, including indirect costs, can be considered a limitation. Also, the two-year separation of control and experimental groups (imposed by program planning), bear potential implications. Finally, freshmen students are not versed in this type of teaching approach, with potential impacts on the results.

Based on the experience of designing and implementing the in-class 
activity and developing this study, further research is suggested, maintaining both the experiential learning approach and the experimental design, mainly with distinct student population and distinct managerial accounting topics. For student population, the suggestion is to develop distinct cases to accommodate the needs and experience of undergraduate, graduate, and executive programs. Also, taking in consideration the student major (undergraduate or graduate programs) and background (executive programs) when designing the activity and selecting teams for the activity. As for variations in managerial accounting, the suggestion is to create experiential activities targeting key knowledge, skills and attitude (a combination of hard and soft skills), based on most challenging topics (e.g., budgeting, pricing, product costing, manufacturing, value chain, cost-volume-profit analysis, transfer pricing, reward systems etc.), according to the program administrators and faculty members based on the vision for the program and professionals, as well as input from the job market. Faculty and program administrators could be motivated by these findings to design similar activities, providing potential opportunities for learners. Proper preparation and training for both faculty and students to explore more experiential learning in their courses seems to be essential and aligned with existing claims from the relevant literature.

\section{REFERENCES}

Accounting Education Change Commission (1990). Position statement number one: Objectives of education for accountants. Retrieved from https://aaahq.org/AECC/pdf/position/pos 1.pdf

Aldrich, C. (2005). Learning by doing. San Francisco: Pfeiffer.

American Accounting Association Committee on the Future Content, Structure and Scope of Accounting Education (The Bedford Committee). (1986). Future accounting education: Preparing for the expanded profession. Issues in Accounting Education, 1(1), 168-195.

American Accounting Association. (2018). The pathways commission: Charting a national strategy for the next generation of accountants. Retrieved from: http://commons.aaaha.org/files/Ob14318188/Pathways Commission Final $R e$ port Complete.pdf .

American Institute of CPAs (AICPA). (2011). CPA Horizons 2025: Core Competencies. Retrieved from: http://www.aicpa.org/research/cpahorizons2025/topfives/corecompetencie s/pages/corecompetencies.aspx

Apostolou, B., Dorminey, J. W., Hassell, J. M., \& Hickey, A. (2018). Accounting education literature review. Journal of Accounting Education, 47, 1-27. doi: 10.1016/j.jaccedu.2019.02.001. 
Apostolou, B., Dorminey, J. W., Hassell, \& Watson, S. F. (2013). Accounting education literature review (2010-2012). Journal of Accounting Education, 31 , 107-161. doi: 10.1016/j.jaccedu.2013.03.001.

Apostolou, B., Hassell, J. M., Rebele, J. E., \& Watson, S. F. (2010). Accounting education literature review (2006-2009). Journal of Accounting Education, 28, 145-197. doi: 10.1016/j.jaccedu.2011.08.001.

Apostolou, B., Watson, S. F., Hassell, J. M., \& Webber, S. A. (2001). Accounting education literature review (1997-1999). Journal of Accounting Education, 19, 1-61. doi: 10.1016/S0748-5751(01)00010-0.

Bandura. A. (1971). Social learning theory. New York: General Learning Co.

Batista, I. V. C. (2004). Percepções dos alunos de negócios acerca de um jogo de empresas online considerando seus estilos de aprendizagem - "Business students' perceptions of an online business game according to their learning styles" (Unpublished Master's Thesis - in Portuguese). University of Sao Paulo, Brazil.

Bollen, L., Janssen, B., \& Gijselaers, W. (2002). Measuring the effect of innovations in teaching methods on the performance of accounting students. In: $A$. Bentzen-Bilkvist, W. H. Gijselaers, and R. G. Milter (Eds.) Educational Innovation in Economics and Business, 7, 21-39. doi: 10.1007/978-94-017-1392-4_2.

Borges, I. T., Santos, A., Abbas, K., Marques, K. C. M., \& Tonin, J. M. F. (2014). Considerable failure in the subject cost accounting: What are the possible motives? Journal of Education and Research in accounting (REPEC), 8(4), 411-426. doi: 10.17524/repec.v8i4.1201.

Braun, K. W. (2013). Custom fabric ventures: An instructional resource in job costing for the introductory managerial accounting course. Journal of Accounting Education, 31, 400-429. doi: 10.1016/j.jaccedu.2013.07.004.

Brewer, P. C., Sorensen, J. E., \& Stout, D. E. (2014). The future of management accounting education: Addressing the competency crisis. Strategic Finance (August), 28-37.

Broome, O. W. \& Morris, M. H. (2005). Multi-entity partnering in accounting education Narrowing the gap between the professional and academia. Advances in Accounting Education, 7, 81-107.

Burch, G. F., Batchelor, J. H., Heller, N. A., Shaw, J., Kendall, W., \& Turner, B. (2014). Experiential learning - What do we know? A meta-analysis of 40 years of research. Developments in Business Simulation and Experiential Learning, 41, 279-283.

Butler, M. G., Church, K. S. \& Spencer, A. W. (2019). Do, reflect, think, apply: Experiential education in accounting. Journal of Accounting Education. doi:10.1016/j.jaccedu.2019.05.001. 
Christensen, C. M. (2008). Disrupting class. New York: McGraw Hill.

Ciulla, J. B. (2000). The working life. New York: Three Rivers Press.

Clark, R. W., Threeton, M. D., \& Ewing, J. C. (2010). The potential of experiential learning models and practices in career and technical education \& career and technical teacher education. Journal of Career and Technical Education, 25(2), 46-62. doi: 10.21061/jcte.v25i2.479.

Cordeiro, R. A. \& Silva, A. B. (2012). Os estilos de aprendizagem influenciam o desempenho academic dos estudantes de financas? "Do learning styles influence the academic performance if students in finance?" Revista de Administração UFSM, 5(2), 243-261.doi:10.5902/198346594541.

Cornachione, E. C. (2004). Tecnologia da educação e cursos de ciências contábeis: Modelos colaborativos virtuais - "Educational technology and accountancy: Virtual collaborative models" (unpublished habilitation dissertation "Livre Docencia"). Sao Paulo: University of Sao Paulo. doi:10.11606/T.12.2007.

Dellaportas, S. \& Hassall, T. (2013). Experiential learning in accounting education: A prision visit. The British Accounting Review, 45, 24-36. doi:10.1016/j.bar.2012.12.005.

Dewey, J. (1916). Democracy and education: An introduction to the philosophy of education. New York: Macmillan Co.

Dimitrios, B., Labros, S., Nikolaos, K., Maria, K., \& Athanasios, K. (2010). Traditional teaching methods vs. teaching through the application of information and communication technologies in the accounting field: Quo Vadis? European Scientific Journal, 9(28), 73-101. doi: 10.19044/esj.2013.v9n28p\%25p.

Duff, A. (2014). Learning styles and approaches in accounting education. In R. M. S. Wilson (Ed.) The Routledge companion to accounting education, pp. 163188. New York: Routledge. doi: 10.4324/9781315889801.

Duff, A. \& McKinstry, S. (2007). Students' approaches to learning. Issues in Accounting Education, 22(2), 183-214. doi:10.2308/iace.2007.22.2.183.

French, G. R. \& Coppage, R. E. (2000). Educational issues challenging the future of the accounting profession. Ohio CPA Journal, 59(3), 69-73.

Gall, M. D., Gall, J. P., \& Borg, W. R. (2003). Educational research: an introduction (7th ed.). Boston: Allyn and Bacon. doi:10.2307/3121583.

Hassal, T. \& Joyce, J. (2014). The use of experiential learning in accounting education. In R. M. S. Wilson (Ed.) The Routledge companion to accounting education (pp. 376-398). New York: Routledge. 
Herath, S. K. (2006). Dilka plastic products company: A teaching case on overhead allocation and pricing decisions using activity-based costing system in a family business. International Journal of Strategic Cost Management, 3(1), 1-16.

Institute of Management Accountants. (2013). Defining the crisis: In our Universities. IMA Competency Crisis. Retrieved from www.competencycrisis.org.

International Accounting Education Standards Board. (2019). Handbook of International Education Pronouncements. New York: IFAC.

Karreman, G. H. (2013). Dynamics of global accounting education (GAE 2012). Tilburg: Tilburg University.

Kirschner, P. A., Sweller, J., \& Clark, R. E. (2006). Why minimal guidance during instruction does not work: An analysis of the failure of the constructivist, discovery, problem-based, experiential, and inquiry-based teaching. Educational Psychologist, 41 (2), 75-86. doi: 10.1207/s15326985ep4102_1.

Knowles, M. S. (1970). The modern practice of adult education: andragogy versus pedagogy. New York: Association Press.

Knowles, M. S. (1980). My farewell address: Andragogy, no panacea, no ideology. Training and Development Journal, August 1980, 48-50.

Knowles, M. S., Holton III, E. F., \& Swanson, R. A. (2005). The adult learner (6 th ed.). Burlington, MA: Elsevier.

Kolb, A. Y. \& Kolb, D. A. (2005). Learning styles and learning spaces: Enhancing experiential learning in higher education. Academy of Management Learning \& Education, 4 (2), 193-212. doi:10.5465/amle.2005.17268566.

Kolb, D. A. (1984). Experiential learning: Experience as the source of learning and development. New Jersey: Prentice-Hall. doi:10.1002/job.4030080408.

Lancaster, K. A. S. \& Strand, C. A. (2001). Using the team-learning model in a managerial accounting class: An experiment in cooperative learning. Issues in Accounting Education, 16(4), 549-567. doi:10.2308/iace.2001.16.4.549.

Lawson, R. A., Blocher, E. J., Brewer, P. C., Morris, J. T., Stocks, K. D., Sorensen, J. E., Stout, D. E., \& Wouters, M. J. F. (2015). Thoughts on competency integration in accounting education. Issues in Accounting Education, 30(3), 149-171. doi:10.2139/ssrn.2477182.

Leite Filho, G. A., Batista, I. V. C., Paulo Jr., J., \& Siqueira, R. L. (2008). Estilos de aprendizagem vs. desempenho academico: Uma aplicação do teste Kolb em acadêmicos no curso de Ciências Contábeis - "Learning styles and academic performance: An application of Kolb with accounting majors." 2008 Congresso USP de Controladoria e Contabilidade. São Paulo. 
Lim, S.; Coetzee, D., Hartmann, B., Fox, A., \& Hearst, M. A. (2014). Initial experiences with small group discussions in MOOCs. Proceedings of the 2014 Learning @ Scale Conference (L@S). Atlanta. doi:10.1145/2556325.2567854.

Lin, Z. J. \& Hunter, A. (1992). Accounting education for the $21^{\text {st }}$ century: A Canadian experiment. Journal of Education for Business, 68(1), 3843.doi:10.1080/08832323.1992.10117584.

Lipsey, M. W. \& Hurley, S. M. (1997). Design sensitivity. In L. Bickman \& D. J. Rog (Eds.) Handbook of applied social research methods, 44-76. New York: Sage. doi:10.4135/9781483348858.

Luft, J. \& Shields, M. D. (2003). Mapping management accounting: Graphics and guidelines for theory-consistent empirical research. Accounting, Organizations and Society, 28(2-3), 169-249. doi:10.1016/S1751-3243(06)010029.

Maher, M. W. (2000). Management accounting education at the millennium. Issues in Accounting Education, 15(2), 335-346. doi: 10.2308/iace.2000.15.2.335.

Manpower Group (2013). Talent shortage survey research. Retrieved from http://www.manpowergroup.us/campaigns/talent-shortage-2013 .

Marshall, P. D., Smith, K. J., Dombrowski, \& Garner, R. M. (2012). Accounting faculty perceptions of the influence of educational and work experiences on their performance as educators. The Accounting Educators' Journal, 22, 73-9.

Matherly, M. \& Burney, L. L. (2013). Active learning activities to revitalize managerial accounting principles. Issues in Accounting Education, 28(3), 653680. doi: 10.2308/iace-50465.

Merchant, K. A. (2010). Paradigms in accounting research: A view from North America. Management Accounting Research, 21, 116-120. doi: 10.1016/j.mar.2010.02.004.

Merriam, S. B. \& Caffarella, R. S. (1999). Learning in adulthood: A comprehensive guide (2nd ed.). San Francisco: Jossey-Bass. doi:10.1 177/0741713607305947.

Mister, W. G. (1983). Note on the interpretation of standard cost variances. Journal of Accounting Education, 1(2), 51-56. doi:10.1016/0748$5751(83) 90006-4$.

Nganga, C. S. N., Ferreira, M. A., Mendes Neto, E. B., \& Leal, E. A. (2013). Estratégias e técnicas aplicadas no ensino de contabilidade gerencial: Um estudo com docentes do curso de Ciências Contábeis - "Teaching trategies and technics applied to managerial accounting: A study with faculty members." Proceedings of the IV Encontro de Ensino e Pesquisa em Administração e Contabilidade. Brasilia. 
Nooghabi, S. N., Iravani, H. \& Fami, H. S. (2011). A study on present challenges on experiential learning of university students (University of Tehran, The Colleges of Agriculture and Natural Resources, Iran). Procedia Social and Behavioral Sciences, 15, 3522-3530. doi:10.1016/j.sbspro.2011.04.329.

Phillips, M. E. \& Graeff, T. R. (2014). Using an in-class simulation in the first accounting class: Moving from surface to deep learning. Journal of Education for Business, 89, 241-247. doi:10.1080/08832323.2013.863751.

Pimentel, A. (2007). A teoria da aprendizagem experiencial como alicerce de estudos sobre desenvolvimento profissional - "Experiential learning theory as the foundation for professional development studies." Estudos de Psicologia, 12(2), 159-168. doi:10.1590/S1413-294X2007000200008.

Pincus, K. V., Stout, D. E., Sorensen, J. E., Stocks, K. D., \& Lawson, R. A. (2017). Forces for change in higher education and implications for the accounting academy. Journal of Accounting Education, 40, 1-18. doi:10.1016/j.jaccedu.2017.06.001.

Pollard, W. B. (1986). Teaching standard costs: A look at textbook differences in overhead variance analysis. Journal of Accounting Education, 4(1), 211-220. doi:10.1016/0748-5751(86)90036-9.

Reis, L. G., Paton, C., \& Nogueira, D. R. (2012). Estilos de aprendizagem: Uma análise dos alunos do curso de Ciências Contábeis pelo método Kolb "Learning styles: Analysis of accounting majors using the Kolb method." Enfoque: Reflexão Contábil, 31 (1), 53-66. doi: 10.4025/enfoque.v31i1.13853.

Rifkin, J. (1995). The end of work. New York: G. P. Putman's Sons.

Salem, M. S. M. (2013). The future of accounting as a subject in a business school: a literature review. The Journal of Human Resource and Adult Learning, 9(2), 62-69.

Santos, D. F., Gassner, F. P., Colauto, R., Antonovz, T., \& Correa, M. D. (2014). Estilos de aprendizagem: Estudo com estudantes de Ciências Contábeis em uma Universidade Pública - "Learning styles: Study with accounting majors in a public university." Revista de Contabilidade da UFBA, 8(1), 37-53.

Schiller, S. (2010). Management accounting in a learning environment. Journal of Accounting \& Organizational Change, 6(1), 123-148. doi: $10.1108 / 18325911011025722$.

Schmitz, L. C., Alperstedt, G. D., van Bellen, H. M., \& Schimitz, J. L. (2013). A aprendizagem experiencial e o desenvolvimento de competências para 0 gerenciamento de projetos - "Experiential learning and project management competency development." IV Encontro de Ensino e Pesquisa em Administração e Contabilidade. Brasilia.

Selingo, J. J. (2013). College (un)bound. New York: Houghton Mifflin Harcourt. 
Siegel, G., Sorensen, J. E., Klammer, T., \& Richtermeyer, S. B. (2010). The ongoing preparation gap in management accounting education: A guide for change. Management Accounting Quarterly, 11 (4), 29-39.

Silberman, M. (2006). Active training (3rd ed.). San Francisco: Pfeiffer.

Sonaglio, A. L. B., Godoi, C. K., \& Silva, A. B. (2012). Estilos de aprendizagem experiencial e aquisição de habilidades: Um estudo com discentes de graduação em administração em instituições de ensino superior "Experiential learning styles and skill acquisition: A study with business administration students at higher education institutions." Administração: Ensino e Pesquisa, 14(1), 123-159. doi:10.13058/raep.2013.v14n1.75.

Sorensen, J. E. (2009). Management accountants in the United States: Practitioner and academic views of recent developments. In: C. S. Chapman, A. G. Hopwood and M. D. Shields. Handbook of management accounting research, 3, 1271-1298. Oxford: Elsevier. doi:10.1016/S1751-3243(07)03004-0.

Spraakman, G. \& Jackling, B. (2014). A conceptual framework for learning management accounting. Accounting Perspectives, 13(1), 61-81. doi: $10.1111 / 1911-3838.12024$.

Slavin, R. E. (1980). Cooperative learning. Review of Educational Research, 50(2), 315-342. doi: 10.3102/00346543050002315.

Stout, D. E. (1996). Experiential evidence and recommendations regarding casebased teaching in undergraduate cost accounting. Journal of Accounting Education, 14(3), 293-317. doi:10.1016/0748-5751(96)00023-1.

Stout, D. E., Rebele, J. E., \& Howard, T. P. (2006). Reasons research papers are rejected at accounting education journals. Issues in Accounting Education, 21 (2), 81-98. doi: 10.2308/iace.2006.21.2.81.

Stewart, J. P. \& Dougherty, T. W. (1993). Using case studies in teaching accounting: A quasi-experimental study. Accounting Education: An International Journal, 2(1), 1-10. doi:10.1080/09639289300000001.

Thomson, J. (2013). Why accounting and finance pros are so difficult to hire. Forbes Online. Retrived from: http://www.forbes.com/sites/jeffthomson/2013/05/30/why-accounting-andfinance-pros-are-so-difficult-to-hire.

United Nations Conference on Trade and Development (UNCTAD). (2011). Model accounting curriculum (revised). Geneve: UNCTAD. Retrieved from: http://unctad.org/en/PublicationsLibrary/diaemisc201 ld l en.pdf.

Valente, N. T. Z., Cornachione, Jr., E. B., Abib, D. B., Pereira, M. M., \& Amaral, I. B. (2008). Estilos de aprendizagem dos alunos do curso de comunicação social 
(jornalismo) da UEPG: Aplicação do inventrio de David Kolb. Revista ADMpg Gestão Estratégica, 1 (1), 57-62.

Villardi, B. Q. \& Vergara, S. C. (201 1). Implicações da aprendizagem experiencial e da reflexao pública para o ensino de pesquisa qualitative e a formação de mestres em administração - "Experiential learning and public reflection: Implications for scientific research teaching and masters development in management education." Revista de Administração Contemporânea, 15(5), 794-814. doi:10.1590/S1415-65552011000500002.

Vinciguerra, B. \& Lafond, C. A. (2011). Using hands-on exercise to teach cost accounting concepts. Journal of Business Cases and Applications, 3, 1-19.

Watson, S. F., Apostolou, B., Hassell, J., M., \& Webber, S. A. (2007). Accounting education literature review (2003-2005). Journal of Accounting Education, 25, 1-58. doi:10.1016/j.jaccedu.2007.01.001.

Way, B. (2013). Jobocalypse: The end of human jobs and how robots will replace them. CreateSpace Independent Publishing.

Webb, L., De Lange, P., \& O'Connell, B. (2009). A programme to expose students to senior executives in the world of accounting: An innovative learning method. Accounting Education: An International Journal, 18(2), 183-205. doi:10.1080/09639280802436723. 


\section{APPENDIX}

Standard costing form for in-class activity

\begin{tabular}{l}
\hline Standard Cos 1 - Planning \\
Step \\
Organize the working group in your \\
miniature plane factory. \\
Planning should involve analyzing \\
the standard product, organizing \\
the manufacturing structure and the \\
tasks assigned to each member of \\
the team.
\end{tabular}

Choose your company name

Record (write) all the steps on the delivered form.

This material must be delivered at the end of the work for analysis by the factory management.

The manufacturing of the product involves materials, labor and indirect costs.

\section{Data Analysis for Planning and Execution}

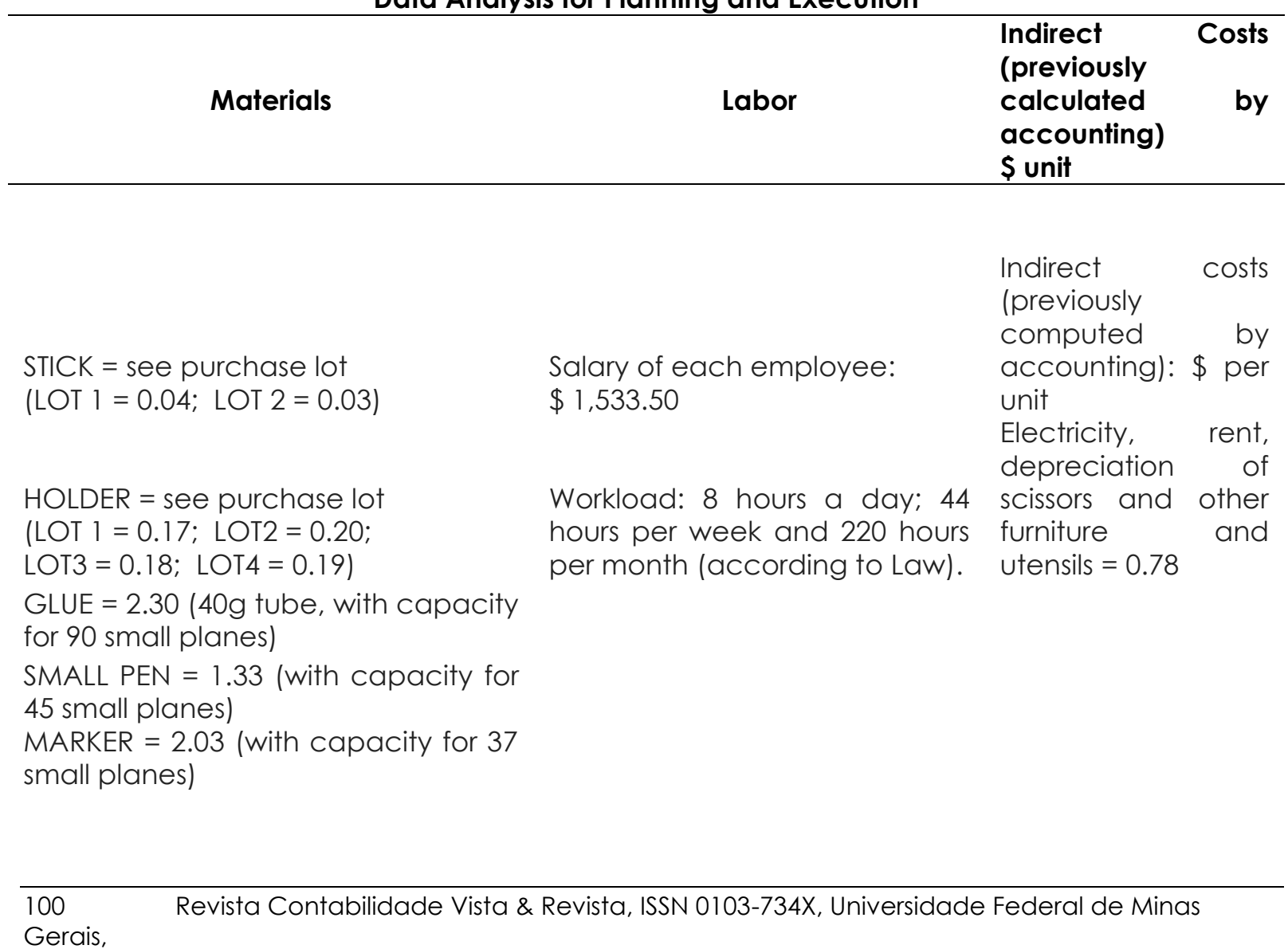




\section{Standard Costing $\$$ unit}

\begin{tabular}{lll}
\hline Holder & 0.17 & \\
Stick & 0.03 & \\
Glue & 0.26 & \\
small pen & 0.03 & \\
Marker & 0.05 & 0.12 per minute \\
& & $(1,533.50 / 220 \quad=$ \\
& & $6.97 / 60=0.12)+0.10$ \\
Labor & 0.22 & \\
Indirect costs & 0.78 & \\
\hline Total & 1.54 & \\
\hline
\end{tabular}




\section{APPENDIX B}

Summary form for in-class recording of the experience

Activities Control

\begin{tabular}{|c|c|c|c|c|c|c|c|c|c|c|}
\hline \multicolumn{11}{|l|}{$\begin{array}{c}\text { Company } \\
\text { name }\end{array}$} \\
\hline Elements & \multicolumn{2}{|c|}{ Cost } & \multicolumn{2}{|c|}{ Total } & \multicolumn{2}{|c|}{ Quantity } & \multicolumn{2}{|c|}{ Price } & \multicolumn{2}{|c|}{ Mix } \\
\hline Cost & $\begin{array}{c}\text { Standard } \\
\$ / \text { un }\end{array}$ & $\begin{array}{l}\text { Actual } \\
\$ / \text { un }\end{array}$ & $\$ /$ un & $\begin{array}{l}\text { F/ } \\
\text { D }\end{array}$ & \$/un & $\begin{array}{l}F / \\
D\end{array}$ & \$/un & $\begin{array}{l}F / \\
D\end{array}$ & $\$ /$ un & $\begin{array}{l}F / \\
D\end{array}$ \\
\hline $\begin{array}{l}\text { Material: } \\
\text { Stick } \\
\text { Holder } \\
\text { Glue } \\
\text { Small pen } \\
\text { Marker }\end{array}$ & & & & & & & & & & \\
\hline Labor & & & & & & & & & & \\
\hline Indirect costs & & & & & & & & & & \\
\hline Total & & & & & & & & & & \\
\hline $\begin{array}{l}\text { Team and } \\
\text { roles }\end{array}$ & & & & & & & & & & \\
\hline $\begin{array}{l}\text { Experiences } \\
\text { of the ream } \\
\text { (errors, hits } \\
\text { and failures) }\end{array}$ & & & & & & & & & & \\
\hline $\begin{array}{l}\text { Process } \\
\text { Organization } \\
\text { Purchasing } \\
\text { Inventory } \\
\text { control } \\
\text { Assembly } \\
\text { Painting/finish } \\
\text { ing } \\
\text { Drying } \\
\text { Quality } \\
\text { control } \\
\text { Delivery }\end{array}$ & & & & & & & & & & \\
\hline Other notes & & & & & & & & & & \\
\hline
\end{tabular}




\section{AUTHORS' CONTRIBUTIONS}

\begin{tabular}{|l|c|c|}
\hline \multicolumn{1}{|c|}{ Contribution } & Luciane Reginato & $\begin{array}{c}\text { Edgard B. } \\
\text { Cornacchione }\end{array}$ \\
\hline $\begin{array}{l}\text { 1. Idealization and conception of the } \\
\text { research subject and theme }\end{array}$ & $\checkmark$ & $\checkmark$ \\
\hline 2. Definition of the research problem & $\checkmark$ & $\checkmark$ \\
\hline 3. Development of Theoretical Platform & $\checkmark$ & $\checkmark$ \\
\hline $\begin{array}{l}\text { 4. Design of the research methodological } \\
\text { approach }\end{array}$ & $\checkmark$ & $\checkmark$ \\
\hline 5. Data collection & $\checkmark$ & $\checkmark$ \\
\hline $\begin{array}{l}\text { 6. Analyses and interpretations of collected } \\
\text { data }\end{array}$ & $\checkmark$ & $\checkmark$ \\
\hline 7. Research conclusions & $\checkmark$ & $\checkmark$ \\
\hline 8. Critical review of the manuscript & $\checkmark$ & $\checkmark$ \\
\hline $\begin{array}{l}\text { 9. Final writing of the manuscript, according } \\
\text { to the rules established by the Journal. }\end{array}$ & $\checkmark$ & \\
\hline 10. Research supervision & & $\checkmark$ \\
\hline
\end{tabular}

